Article

\title{
Podravka and Slavonka Varieties of Pepper Seeds (Capsicum annuum L.) as a New Source of Highly Nutritional Edible Oil
}

\author{
Tanja Cvetković ${ }^{1, *}$, Jasmina Ranilović ${ }^{1}$, Davorka Gajari ${ }^{1}{ }^{1}$, Helena Tomić-Obrdalj ${ }^{1}$, \\ Drago Šubarić ${ }^{2}$, Tihomir Moslavac ${ }^{2}$, Ana-Marija Cikoš ${ }^{2}$ and Stela Jokić ${ }^{2, * \mathbb{D}}$ \\ 1 Research and Development, Podravka Ltd., Ante Starčevića 32, 48000 Koprivnica, Croatia; \\ jasmina.ranilovic@podravka.hr (J.R.); davorka.gajari@podravka.hr (D.G.); \\ helena.tomic-obrdalj@podravka.hr (H.T.-O.) \\ 2 Faculty of Food Technology Osijek, Josip Juraj Strossmayer University of \\ Osijek, Franje Kuhača 20, 31000 Osijek, Croatia; dsubaric@ptfos.hr (D.Š.); tihomir.moslavac@ptfos.hr (T.M.); \\ acikos@ptfos.hr (A.-M.C.) \\ * Correspondence: tanja.cvetkovic@podravka.hr (T.C.); stela.jokic@ptfos.hr (S.J.); Tel.: +385-48-651-128 (T.C.); \\ +385-31-224-333 (S.J.)
}

Received: 19 July 2020; Accepted: 4 September 2020; Published: 9 September 2020

\begin{abstract}
The aim of this study was to evaluate Croatian pepper seed varieties (Podravka and Slavonka) as a new source of added value ingredients. Pepper seed is mostly considered a by-product. For the first time, the pepper (Capsicum annuum L.) seeds of the Slavonka and Podravka varieties were examined as the source material for oil production by the two methods of extraction: cold pressing (CP) and supercritical $\mathrm{CO}_{2}$ extraction $\left(\mathrm{SC}-\mathrm{CO}_{2}\right)$. Further, fatty acid profile, tocopherols, and sensory analysis of the oils were examined, as well as the chemical characteristics and antioxidant potential of seed flour. The antioxidant potential of pepper seed flour was different between varieties (Podravka 107 antioxidant unit (AU); Slavonka 70 antioxidant unit (AU)). The Podravka variety pepper seed oil has shown higher $\gamma$-tocopherol content (CP $80.1 \mathrm{mg} / 100 \mathrm{~g}$; SC- $\mathrm{CO}_{2}$ extraction $65.3 \mathrm{mg} / 100 \mathrm{~g}$ ) than the Slavonka variety (CP $65.3 \mathrm{mg} / 100 \mathrm{~g}$; $\mathrm{SC}-\mathrm{CO}_{2}$ extraction $\left.16.0 \mathrm{mg} / 100 \mathrm{~g}\right)$. According to the obtained results, cold pressing $(\mathrm{CP})$ would be a more favourable method for pepper seed oil extraction, taking into account sensory evaluation and nutritional quality. The pepper seed oil has potential for culinary application with a nutritional quality comparable to vegetable oils of a higher price class.
\end{abstract}

Keywords: pepper seed; Capsicum annuum; oil; quality; bioactive compounds; sensory analysis

\section{Introduction}

A fast-growing world population, deficiencies in feed supply, and global bioenergy demands are the main reasons for the increasing amount of research into by-products and waste from agro-food processing. It has been found that up to $39 \%$ of food waste is generated during manufacturing, and $5 \%$ is generated within food distribution systems. So, the utilization of food processing waste is very important for a sustainable agricultural economy [1,2]. According to botanical classes, peppers as plant vegetables are within the Solanaceae family and the Capsicum genus. Within the genus, the Capsicum annuиm L. species is the most cultivated one and there are a lot of varieties of Capsicum annuum L. [3]. Annual global production reached approximately 3.9 million tons (dried chillies and peppers) in 2016 [4]. Asia is the largest pepper producer, accounting for 70\% of global production [5]. The pepper fruits (Capsicum annuum L.) in different forms, colour, taste, shape, and pungency, and be used fresh, for cooking, or processed into sauces, condiments, spreads, powders, and other products [4]. 
Available published research has shown that pepper seeds are a great source of high quality oil, which can be used in nutrition, as well in the pharmaceutical, chemical, and cosmetic industries, due to their capability of absorbing ultraviolet (UV) radiation [6]. The mentioned research has shown that pepper seeds (Capsicum annuum) could be considered a sustainable source of dietary fibres, which are present at a high percentage (60.96\% of total dietary fibres).

El-Adaway and Taha [7] were the first to evaluate the chemical composition of oil and proteins from pepper seeds. They reported that pepper seeds (Capsicum annuum) are a good source of protein $(24 \%)$ and oil (26\%). Subsequently, da Silva et al. [8] confirmed that seeds have high antioxidant potential due to their content of polyphenols, carotenoids, and terpenes.

The oil obtained from the pepper seeds has a pleasant taste which can be compared to other edible oils such as peanut oil [9] and sunflower oil [10]. The oil colour is reddish yellow, indicating the presence of carotenoids. In terms of physicochemical characteristics, pepper seed oil is in the range of other edible oils [11].

Reports in the literature have shown that the oil content of pepper seeds in the Capsicum genus varied from $14.6 \%$ to $35.9 \%$ among cultivated species, as well as that seed oil content varied between seven Capsicum annuum varieties from $16.4 \%$ to $35.9 \%$ [3] and from $8.5 \%$ to $32.6 \%$ among varieties from different locations in Italy and Turkey [12].

Regarding fatty acid composition, the variation between the species and varieties was small. The predominant fatty acid in pepper seed oils of Capsicum annuum was linoleic acid, which accounted for between $69.5 \%$ and $74.7 \%$ in different varieties [12] and from 70.9 to $74.3 \%$ according to Koncsek [13].

Further, according to Chouaibi [14], the total phenolic compounds and $\gamma$-tocopherol contents of pepper seed oils (Capsicum annuum) are influenced by the extraction techniques, as well as their antioxidant activities.

Podravka and Slavonka are among the first Croatian varieties of peppers (Capsicum annuum L.) with the UPOV (International Union for the Protection of New Varieties of Plants) certificate, and they are also added to the List of Varieties of the Republic of Croatia [15].

The names of the varieties are associated with two regions in the north of Croatia suitable for growing peppers. Podravka and Slavonka are medium early varieties of peppers, suitable for processing in the industry, so they are mostly used in the production of chutney and other condiments.

The aim of this study was to examine the nutritional, chemical, and sensory quality of oil obtained from the Podravka and Slavonka varieties of pepper seeds (Capsicum annuum L.) by the two green extraction methods ( $\mathrm{CP}$-cold pressing; $\mathrm{SC}-\mathrm{CO}_{2}$ - supercritical $\mathrm{CO}_{2}$ extraction) at the laboratory level.

\section{Materials and Methods}

\subsection{Materials}

Dried pepper seeds (Capsicum annuum L.) of the Podravka and Slavonka varieties were obtained in September of 2018 from the plant Črešnjevica in the Podravina region (north-western part of Croatia).

The pepper fruits (Capsicum annuum L.) of the Podravka and Slavonka varieties are conical oblong red-coloured fruits, with the average weight of $165 \mathrm{~g}$ (Podravka) and $150 \mathrm{~g}$ (Slavonka). There are no big differences in botanical performances between the two varieties of fruit [16]. The pepper fruits and seeds of the Podravka and Slavonka varieties used in this study are shown in Figures 1 and 2.

Prior to analysis, the dried pepper seeds were ground into powder in an IKA A11 Basic laboratory mill. The purity of $\mathrm{CO}_{2}$ used for extraction was $99.97 \%(w / w)$ (Messer, Osijek, Croatia). Industry FAME mix 37 standard for fatty acid analysis was purchased from Restek (Bellefonte, PA, USA). 

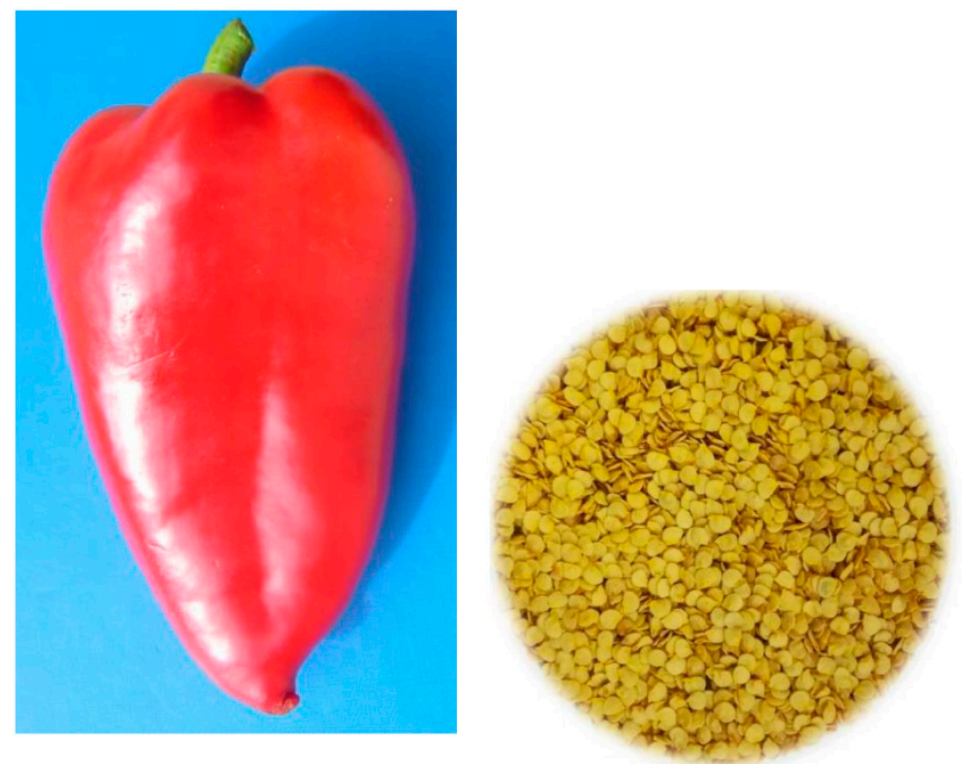

Figure 1. Fruit and seeds of the pepper (Capsicum annuum L.) variety Podravka.
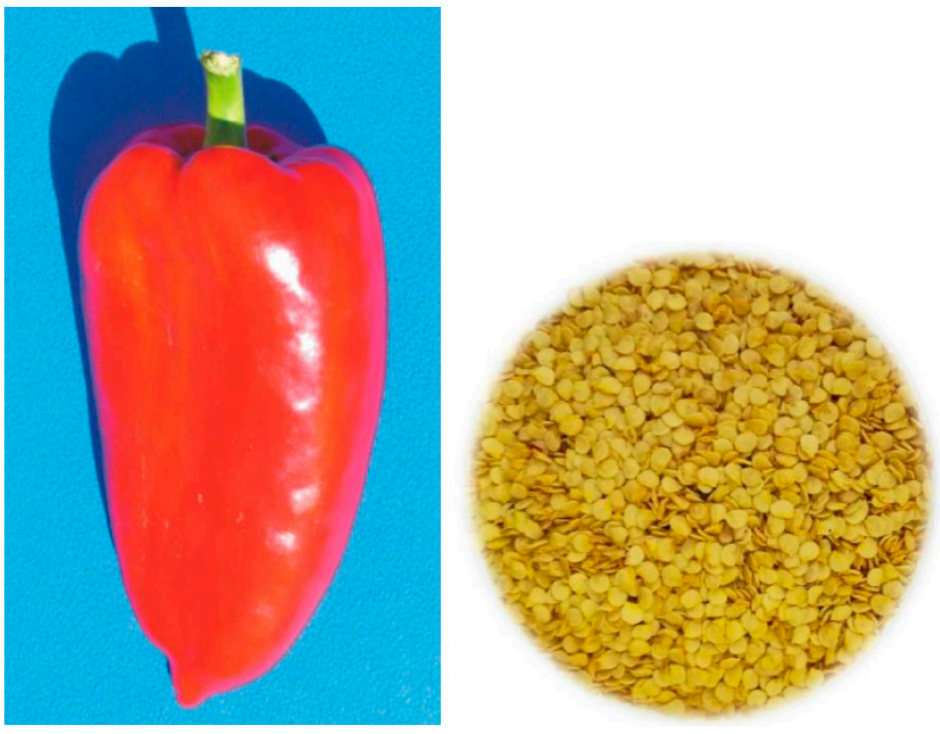

Figure 2. Fruit and seeds of the pepper (Capsicum annuum L.) variety Slavonka.

The oil obtained from both varieties and both extraction methods was packed into dark glasses and kept in a dry place at room temperature $\left(20^{\circ} \mathrm{C}\right)$ prior to the analysis.

All the chemicals and standards were purchased from Supelco (Bellefonte, PA, USA), Sigma (MO-St.Louis; PA-Allentown, and WY-Laramie, USA), Sigma-Aldrich (St. Louis, MO, USA; Germany; Oakville, ON, Canada), Honeywell (Charlotte, NC, USA), Nu-chek-prep (Elysian, MN, USA), Merck (St. Louis, MO, USA; Darmstadt, Germany), Acros Organics (Morris Plains, NJ, USA; Hangzhou, China; Geel, Belgium), Carlo Erba (Milano, Italy), Ultra Scientific (Bologna, Italy), HPC (Cunnersdorf, Germany), CHEM-LAB (Zedelgem, Belgium), VWR International (Radnor, PA, USA) and the reference material for determination of dietary fiber (CRM T2486QC, matrix is wheat flour) was purchased from FAPAS (York, UK). 


\subsection{Methods}

\subsubsection{Supercritical $\mathrm{CO}_{2}\left(\mathrm{SC}-\mathrm{CO}_{2}\right)$ Extraction of the Podravka and Slavonka Pepper Seeds}

The experiment was performed in the SC- $\mathrm{CO}_{2}$ system explained in detail by Jokić et al. [17]. The extraction vessel is made from a stainless steel bar (AISI 304) O.D. $100 \mathrm{~mm}$ and height $500 \mathrm{~mm}$. A stainless steel rod is drilled (center hole) with a $\varnothing 40 \mathrm{~mm}$ bore for $400 \mathrm{~mm}$, so the volume of the extractor is $500 \mathrm{~mL}$. The upper inside part of the extraction cell is polished to plug well gaskets. The plug has a built-in filter element that should prevent withdrawal of material. The filter element has the ability to filter particles of 2 microns nominal and 10 microns absolute (Norman Ultraporous 4202T-6T-2M). High-pressure seamless tubes of dimensions $10 \times 2 \mathrm{~mm}$ are connected to each other by Ermeto couplings (flat, knees, tees). The pressure extraction cell is controlled by two WIKA manometers (model 212.20) $60 \mathrm{MPa}$ and one WIKA manometer (model 212.20) $4 \mathrm{MPa}$ for pressure in the separator. The extraction cell is heated with a glass fiber electric heater, controlled by a centralized system and Solid State Relays (SSR). Temperature is controlled by means of a PID regulator set to a maximum temperature of $80^{\circ} \mathrm{C}$ with lag delay compensation, due to the large mass of the extraction cell. Temperature measurements and regulation of the extraction cell are performed using an integrated temperature sensor within the cell and an additional temperature sensor measuring output gas temperature. The input $\mathrm{CO}_{2}$ line towards the extraction cell is preheated using a heat exchanger powered by a water heating system. The temperature is regulated using a standard PID regulator, taking into account the differential temperatures of water lines and output gas line. Pressure in the separator is regulated by means of an electromechanical solution for controlling the pressure valve, with a pressure sensor working as a feedback. The pump used to pressurize liquid $\mathrm{CO}_{2}$ is a Haskel ${ }^{\circledR}$ MS-71. Liquid $\mathrm{CO}_{2}$ is precooled through the $\mathrm{SS}$ coil at $-18^{\circ} \mathrm{C}$, cooled by an ethylene glycol/ethanol cooling bath. A check valve is located after the pump to prevent eventual $\mathrm{CO}_{2}$ flow disorders. Prior to the input extraction vessel, $\mathrm{CO}_{2}$ is preheated through a stainless steel double coil at the temperature of extraction. After the extraction vessel, the high pressure is reduced by a high-pressure valve (B-HV) to the desirable pressure. Valves and tubing are heated to a temperature of $0{ }^{\circ} \mathrm{C}$ due to high-pressure drop. The flow of $\mathrm{CO}_{2}$ is controlled through a Matheson FM-1050 (E800) flow meter.

In this study, ground dried pepper seeds, of the Podravka and Slavonka varieties, in the amount of $100 \mathrm{~g}$, were placed into the extractor vessel. The extracts of both seed varieties were collected in previously weighed glass tubes. The extraction process took $3 \mathrm{~h}$, and all of the raw material was exhausted. The amount of extract obtained after the defined time was established by weight, using a balance with a precision of $\pm 0.0001 \mathrm{~g}$. The separator conditions were $15 \mathrm{bar}$ and $25^{\circ} \mathrm{C}$. The $\mathrm{SC}-\mathrm{CO}_{2}$ was performed at the extraction pressure of 300 bar and the temperature of $40{ }^{\circ} \mathrm{C}$, at a mass flow rate of $2 \mathrm{~kg} / \mathrm{h}$. The oil yield obtained from Podravka seeds was 26.2\%, and from Slavonka seeds, $25.5 \%$.

\subsubsection{Cold Pressing of the Podravka and Slavonka Pepper Seeds}

Cold pressed oil from pepper seeds, of the Podravka and Slavonka varieties, was obtained on a laboratory screw press (KOMET, screw oil expeller Ca 59 G, Germany). The following parameters were used: head press temperature of $93^{\circ} \mathrm{C}$, frequency of $22 \mathrm{~Hz}$, and nozzle interior diameter of $15 \mathrm{~mm}$. The temperature of the obtained crude oil was $38^{\circ} \mathrm{C}$, the oil was left for sedimentation and the clear oil was then separated from the precipitate. The oil yield obtained by cold pressing from Podravka seeds was $22.7 \%$, and $20.21 \%$ from Slavonka seeds.

\subsubsection{Pepper Seed Flour-Nutritional and Chemical Analysis}

\section{Determination of Energy Value}

The value obtained by calculation and a note on the contents of fats, proteins, carbohydrates, and dietary fibre (where present), were expressed in kcal or kJ per $100 \mathrm{~g}$ of food in accordance with current legislation [18] on the nutritional labelling of food products. 


\section{Determination of Protein Content}

Protein content was determined by the Dumas method [19], where an aliquot of a sample was subjected to combustion with oxygen using an automatic instrument (FP-528, LECO Inc., St Joseph, MI, USA), which measures the amount of total nitrogen present in the sample. The combustion temperature was $950^{\circ} \mathrm{C}$, while the time of the analysis process was $210 \mathrm{~s}$. The nitrogen value obtained was multiplied by the specific conversion factor 6.25 related to the analysed matrix [20].

\section{Determination of Fat Content}

Warm acid hydrolysis was performed with 1:4 $\mathrm{HCl}: \mathrm{H}_{2} \mathrm{O}$ solution, where $4 \mathrm{~g}$ of the sample was used during $60 \mathrm{~min}$ from the time of boiling. Filtration and drying of the filter were done in an oven at $70^{\circ} \mathrm{C}$. Hence, hot extraction with petroleum ether lasted for $3 \mathrm{~h}$ using the Soxhlet apparatus. At the end of the extraction, the solvent was evaporated and the residual fat was determined by gravimetric analysis [21].

\section{Determination of Saturated Fatty Acid Content}

The methyl esters obtained by transmethylation of the fat substance were analysed on the gas chromatograph 7890A (Agilent Technologies, Lake Forest, CA, USA) with a capillary column CP-Sil 88 (length $100 \mathrm{~mm}$; diameter $0.25 \mathrm{~mm}$; phase thickness $0.2 \mu \mathrm{m}$ ) (Agilent Technologies, Lake Forest, CA, USA), splitting ratio of 10:1, and a flame-ionization detector (Agilent, Lake Forest, CA, USA) with a sample volume of $1 \mu \mathrm{L}$. The starting temperature was $60^{\circ} \mathrm{C}$ with holding time of $5 \mathrm{~min}$. The oven temperature was increased by a rate of $15^{\circ} \mathrm{C} / \mathrm{min}$ to $165^{\circ} \mathrm{C}$, held for $1 \mathrm{~min}$, then increased according to the rate of $2{ }^{\circ} \mathrm{C} / \mathrm{min}$ to $225^{\circ} \mathrm{C}$, and held for $19 \mathrm{~min}$. The carrier gas was helium $(99.9999 \%)$ at the constant flow rate of $0.5 \mathrm{~mL} / \mathrm{min}$. Hydrogen flow was $40 \mathrm{~mL} / \mathrm{min}$, air flow was $450 \mathrm{~mL} / \mathrm{min}$, and the makeup gas flow (nitrogen) was $24 \mathrm{~mL} / \mathrm{min}$. Composition was determined using the response factors obtained from the analysis of a reference mixture of methyl esters of known composition, under conditions identical to those used for the sample. Saturated fatty acids were expressed with respect to the fat content of the sample [22].

\section{Determination of Carbohydrate Content}

The value of the carbohydrate content was obtained by calculation, considering the known values of fats, proteins, dietary fibres, water content, and ash [23].

\section{Determination of Sugar Content}

The sample was extracted in hot water and stirred for $30 \mathrm{~min}$. Aqueous extract, in which internal standard (inositol for monosaccharides; fructose, glucose and trehalose for disaccharides; saccharose, lactose, maltose), was appropriately added, and was analysed after derivatization on the gas chromatograph 6890N (G1530N) (Agilent Technologies, Lake Forest, CA, USA) with a capillary column in fused phase-linked silica DB1 type (length: $30 \mathrm{~m}$, internal diameter: $0.25 \mathrm{~mm}$, phase thickness: $0.25 \mu \mathrm{m}$ ), a split injector (split ratio 15:1; split flow $15 \mathrm{~mL} / \mathrm{min}$ ), and a flame-ionization detector (FID; Agilent Technologies, Lake Forest, CA, USA), with the sample injection volume of $1 \mu \mathrm{L}$. The starting temperature was $160^{\circ} \mathrm{C}$ with holding time for $2 \mathrm{~min}$. Oven temperature was increased according to the rate of $12{ }^{\circ} \mathrm{C} / \mathrm{min}$ to $280{ }^{\circ} \mathrm{C}$, held for $8 \mathrm{~min}$, then increased according to the rate of $20^{\circ} \mathrm{C} / \mathrm{min}$ to $290^{\circ} \mathrm{C}$, and held for $10 \mathrm{~min}$. The carrier gas was helium $(99.9999 \%)$ at the constant flow rate of $1 \mathrm{~mL} / \mathrm{min}$. Hydrogen flow was $40 \mathrm{~mL} / \mathrm{min}$, air flow was $450 \mathrm{~mL} / \mathrm{min}$, and the makeup gas flow (nitrogen) was $44 \mathrm{~mL} / \mathrm{min}$. The composition was determined using the calibration curve for sugars with concentrations ranging from 25 to $1000 \mathrm{mg} / \mathrm{L} \mathrm{[24].}$ 


\section{Determination of Dietary Fibre Content}

Dietary fibre was determined gravimetrically, after enzymatic digestion with a-amylase $\left(100{ }^{\circ} \mathrm{C}\right.$ water bath, to provide gelatinisation, hydrolysis, and depolymerisation of starch), protease (water bath at $60{ }^{\circ} \mathrm{C}$ to solubilise and depolymerise proteins), and amyloglucosidase (water bath $60{ }^{\circ} \mathrm{C}$ to hydrolyse the starch fragment to glucose). Samples were run in duplicates and treated with ethyl alcohol to precipitate soluble fibre and remove depolymerised protein and glucose (from starch). The total residue was washed with ethyl alcohol and acetone, dried, and then weighed. Residual proteins and ashes were then determined on the obtained residue. Total fibre content was provided by the weight of the residue after subtraction of the ash and residual protein content, all brought back to $100 \mathrm{~g}$ of sample. The samples with fat quantity of $>10 \%$ were subjected to a preliminary treatment with an ethanol-petroleum ether mixture. The analytical value does not include soluble fibres, which are non-precipitable by ethanol (e.g., inulin, resistant maltodextrins, etc.), and which were detected using specific methods [25].

\section{Determination of Sodium Content}

An aliquot of homogenized sample was mineralized with $70 \% \mathrm{HNO}_{3}$ at $120{ }^{\circ} \mathrm{C}$ in a heating block for $90 \mathrm{~min}$. The obtained solution was then quantitatively brought to volume, filtered in a test tube, and appropriately diluted. Instrumental determination was performed using inductively coupled plasma-optical emission spectroscopy (ICP-OES). The method is validated and accredited in compliance with the EN ISO/IEC 17025 standard [26]. Instrument calibration was performed using certified standards (sodium standard, ultra scientific analytical solutions $10,000 \mu \mathrm{g} / \mathrm{mL}$ in water and diluted nitric acid). Control tests were conducted through international Proficiency Tests.

\section{Determination of Water Content and Dry Matter}

The sample was dried in an oven for 6-8 $\mathrm{h}$ (minimum time) at $103^{\circ} \mathrm{C}$, directly in the weighing bottle, without the addition of sand. The water content was then determined by weight and by the calculation of the residue [27].

\section{Determination of Ash Content}

An aliquot of sample (about 2-3 g) was weighed in a porcelain or platinum calibrated container (capsule or crucible) and was then incinerated at $550{ }^{\circ} \mathrm{C}$ until the organic substance completely combusted and a constant mass was reached. Ash content was recovered by determining the weight of the obtained residue [28].

\section{Determination of Vitamin C Content}

The sample was extracted with water in the presence of DI-dithiothreitol (DTT) in an ultrasonic bath. After appropriate dilution and filtration, final HPLC determination was performed with a diode array detector (DAD) (Varian Prostar 330). The determination was carried out by a liquid chromatrograph (Varian 9012Q) with chromatographic column C18 $(5 \mu \mathrm{m} ; 3.0 \times 250 \mathrm{~mm})$. The mobile phase for HPLC-DAD detection was ascorbic buffer at $\mathrm{pH}=5$ composed of $0.3 \%$ anhydrous sodium acetate $+0.3 \%$ of Tetrabutylammonium hydrogen sulfate $+0.07 \%$ of Potassium chloride in water by HPLC and brought to $\mathrm{pH}=5$ with glacial acetic acid. Isocratic elution with $100 \%$ mobile phase was performed for $10 \mathrm{~min}$ (flux $0.6 \mathrm{~mL} / \mathrm{min}$ ). Due to interferences, the final determination was carried out in (LC-MS/MS). The sample was extracted with a solution of DI-dithiothreitol (DTT) in water (20 mg/L), in an ultrasonic bath for $2 \mathrm{~min}$. The obtained extract was filtered using HV-PVDF filters (internal diameter $0.45 \mu \mathrm{m}$ ) and diluted in the DTT solution, depending on the concentration of the sample in the final extract, which was within the concentration range of the calibration curve. The final determination was carried out by a liquid chromatograph (Waters Acquity UPLC, The Netherlands) and a mass spectrometer (Applied Biosystem API 4000) with a $1.8 \mu \mathrm{m}$ column, $2.1 \times 150 \mathrm{~mm}$ (Acquity 
UPLC HSS T3). The mobile phases (Table 1) that were used were A: $0.002 \mathrm{M}$ ammonium formate buffer with $0.1 \%(w / v)$ formic acid in water and $1 \%$ acetonitrile; B: $0.025 \%$ formic acid $(w / v)$ in acetonitrile. The determination was performed according to the method described by Novakova et al. [29].

Table 1. Elution program for Vitamin C.

\begin{tabular}{cccc}
\hline Time (min) & Mobile Phase A(\%) & Mobile Phase B(\%) & Flux (mL/min) \\
\hline 0 & 100 & 0 & 0.4 \\
2.5 & 100 & 0 & 0.4 \\
3.0 & 80 & 20 & 0.4 \\
5.0 & 60 & 40 & 0.4 \\
5.20 & 0 & 100 & 0.4 \\
5.80 & 0 & 100 & 0.4 \\
6.0 & 100 & 0 & 0.4 \\
7.0 & 100 & 0 & 0.4 \\
\hline
\end{tabular}

Determination of Total Polyphenols

The method applied was based on the extraction of polyphenols with methanol in an acid environment and subsequent reaction with the Folin-Ciocalteu reagent in the presence of a sodium bicarbonate solution. The produced blue colour has maximum absorption at $\lambda=765 \mathrm{~nm}$ and is proportional to the content of phenolic compounds. Polyphenols are determined by spectrophotometric analysis considering an external curve prepared from gallic acid [30-32].

\section{HPLC Determination of Capsaicins}

Total capsaicins were determined according to ISO 7543-2 [33] for the spices as follows; the sample was extracted in Soxhlet for $8 \mathrm{~h}$ with tetrahydrofuran (THF). The obtained extract was transferred quantitatively and diluted in THF in a volumetric flask. An aliquot of the extracts was filtered in a vial with PTFE filters ( $0.45 \mu \mathrm{m}$ pores like Millipore or equivalent).

The final determination was carried out in the liquid chromatograph 1200 (Agilent Technologies, Lake Forest, CA, USA) with the column Phenomenex Gemini $5 \mu \mathrm{m} \mathrm{C18} 110(250 \times 3.0 \mathrm{~mm})$ and the diode array detector 1100 (DAD; Agilent Technologies, Lake Forest, CA, USA). The mobile phases (Table 2 ) were $1 \%$ of acetic acid in water $+5 \%$ acetonitrile for $\mathrm{A}$ and $100 \%$ methanol for $\mathrm{B}$. The conditions during the analysis were in accordance with ISO 7543-2 [33].

Table 2. Elution program for capsaicins.

\begin{tabular}{cccc}
\hline Time (min) & Mobile Phase A(\%) & Mobile Phase B(\%) & Flux (mL/min) \\
\hline 0 & 40 & 60 & 0.650 \\
17.50 & 30 & 70 & 0.650 \\
18.00 & 0 & 100 & 0.650 \\
Stop time: & $22.50 \mathrm{~min}$ & & \\
Post time: & $4.00 \mathrm{~min}$ & & \\
\hline
\end{tabular}

Determination of Antioxidant Power

Antioxidant power $(A P)$ was determined according to the method described by Jung et al. [34] based on antioxidant capacity and antioxidant activity. Antioxidant capacity and reactivity were measured using Electron Spin Resonance (ESR) spectroscopy. The measurements discussed in this article were performed with the X-band ESR spectrometer Miniscope MS 300 (Magnettech, Germany) and the following technical parameters: $60 \mathrm{G}$ sweep width, $100 \mathrm{Gain}, 1 \mathrm{G}$ modulation amplitude, $7 \mathrm{~mW}$ attenuation, $3365 \mathrm{G}$ central field, $0.14 \mathrm{sec}$ time constant. Antioxidative power $(A P)$ is a parameter able to quantify both the reaction capacity and velocity of antioxidants. The test radical DPPH (2,2-diphenyl-1picryl-hydrazyl) was used as a detector molecule. At least 3 concentrations of the test 
sample were prepared in ethanol (99\%) and added to DPPH to obtain an initial radical concentration of $0.1 \mathrm{mM}$. The signal intensity decay of each concentration of the test samples was recorded at different time intervals during the reaction until saturation was reached and all antioxidant-active molecules had reacted with the test radical. A first order kinetic was obtained from these intensities for each concentration set. The kinetic parameters were used to calculate reaction time $(t r)$ and the static parameters were used to calculate characteristic weight $(w c)$. Both parameters were used to calculate the $A P$ by means of the following equation (Equation (1)), where $N$ is the quantity of reduced free radicals characterized by free electrons (spins) or the quantity of applied concentration c of $D P P H$-spins, and $R A$ is the reduction amplitude:

$$
A P=\frac{R A \times N(D P P H)}{\operatorname{tr} \times w c}
$$

For a direct comparison of different antioxidants, the $A P$ method was standardized to the activity of vitamin $C$ (Ascorbic acid). The antioxidative activity of a solution of $1 \mathrm{ppm}$ of vitamin $C$ was defined as an antioxidative unit (AU).

\subsubsection{Pepper Seed Oil—Chemical and Sensory Evaluation}

\section{Determination of Fatty Acid Composition}

Preparation of fatty acid (FA) methyl esters was carried out according to the HRN EN ISO 12966-2:2011 [35] standard. The prepared FA methyl esters were analysed by gas chromatography according to HRN EN ISO [36]. The gas chromatograph 7890B (Agilent Technologies, Lake Forest, CA, USA) with a HP88 capillary column, $100 \mathrm{~m}$ long with a diameter of $0.25 \mathrm{~mm}$, and a 0.20 microns thickness of the stationary phase (Restek, Bellefonte, PA, USA), a split injector (temperature $250^{\circ} \mathrm{C}$ ), and a flame-ionization detector (temperature $250{ }^{\circ} \mathrm{C}$ ) were used with a sample volume of $1 \mu \mathrm{L}$. The starting temperature was $120^{\circ} \mathrm{C}$ with holding time of $1 \mathrm{~min}$. The oven temperature was increased according to the rate of $10^{\circ} \mathrm{C} / \mathrm{min}$ to $175^{\circ} \mathrm{C} / \mathrm{min}$, held for $10 \mathrm{~min}$, then increased according to the rate of $5{ }^{\circ} \mathrm{C} / \mathrm{min}$ to $210{ }^{\circ} \mathrm{C}$ and held for $5 \mathrm{~min}$, and after that according to the rate of $5{ }^{\circ} \mathrm{C} / \mathrm{min}$ to $230{ }^{\circ} \mathrm{C}$ with holding for $5 \mathrm{~min}$. The carrier gas was helium $(99.9999 \%)$ at the constant flow rate of $2 \mathrm{~mL} / \mathrm{min}$. The hydrogen flow was $40 \mathrm{~mL} / \mathrm{min}$, air flow was $450 \mathrm{~mL} / \mathrm{min}$, and the makeup gas flow (nitrogen) was $30 \mathrm{~mL} / \mathrm{min}$. FA methyl esters in samples were identified by comparison with retention times of 37 FA methyl ester standards at the same conditions. Prior to standard and sample analysis, certified reference material (CRM) was prepared and analysed at the same conditions. The results were expressed as the percentage (\%) of individual fatty acids to total fatty acids.

\section{HPLC Determination of Tocopherols}

The sample, placed in a volumetric flask, was dissolved and extracted in isopropanol in an ultrasonic water bath for $30 \mathrm{~min}$. An obtained aliquot of the extract was filtered in vials with PTFE filters $(0.45 \mu \mathrm{m})$. The final determination was carried out in the liquid chromatograph 1290 infinity series (Agilent Technologies, Lake Forest, CA, USA) with the column Kinetex 1.7u PFP 100A $(150 \times 2.10$ $\mathrm{mm}$ ), with a fluorometric detector 1290 infinity series (Agilent Technologies, Lake Forest, CA, USA). The mobile phases (Table 3 ) were $0.04 \%$ phosphoric acid in water $+5 \%$ acetonitrile for A and $100 \%$ acetonitrile for $\mathrm{B}$. The analysis was performed according to the conditions described in the Commission Directive 2000/45/EC [37]. 
Table 3. Elution program for tocopherols.

\begin{tabular}{cccc}
\hline Time (min) & Mobile Phase A(\%) & Mobile Phase B(\%) & Flux (mL/min) \\
\hline 0 & 50 & 50 & 0.6 \\
5.0 & 35 & 65 & 0.6 \\
15.0 & 25 & 75 & 0.6 \\
15.1 & 0 & 100 & 0.6 \\
16.0 & 0 & 100 & 1.0 \\
Stop time: & 19 min & & \\
Post time: & $3.00 \mathrm{~min}$ & & \\
\hline
\end{tabular}

Sensory Evaluation

Quantitative descriptive analysis ${ }^{\circledR}\left(\mathrm{QDA}^{\circledR}\right)$ was used for the purposes of the sensory profile of pepper seed oil. The descriptive panel consisted of 6 female and 2 male participants aged between 35 and 48. Before the analysis, the panel had training sessions for the period of two months, two hours per week. The panel developed a lexicon of 11 sensory attributes for red pepper seed oil samples. Attributes were based on previous research regarding descriptive sensory assessment of vegetable oils (olive, safflower seed, cottonseed etc.) [38-41]. QDA ${ }^{\circledR}$ was carried out in two replicates by using a $15-\mathrm{cm}$ scale anchored by none on the left, and strong on the right. Samples were served in transparent glass cups covered by an aluminium lid, coded by a 3-digit number. Participants got the amount of $15 \mathrm{~mL}$ served at room temperature $\left(24^{\circ} \mathrm{C}\right)$. A slice of apple and carbonated water was used for neutralization. Samples were presented monadically to judges in a random order. Acceptability testing was performed by using a hedonic scale from 9 (like extremely) to 1 (dislike extremely) on a group of 60 untrained consumers. Profiling analyses and consumer testing were performed in EyeQuestion Data Collection v. 4.11.40 (EyeQuestion Software - Logic8 B.V. - Nieuwe Aamsestraat, The Netherlands).

\section{Statistical Analysis}

All instrumental analyses on Podravka and Slavonka seed varieties were measured in triplicate. The results are presented as the mean $(n=3) \pm$ standard error. Statistical analysis for significant difference between varieties (Table 4) and extraction methods (Tables 5 and 6) were performed by Student T-test and Two-way ANOVA with repetition and Tukey's Honestly Significant Difference (HSD) test for significance between varieties and extraction methods. Statistical significance for all tests was set at $p<0.05$.

Statistical analysis for sensory profiling data included descriptive statistics, Two-way ANOVA and Tukey's HSD test for significance between varieties and extraction methods and multifactorial Principal component analysis (PCA). Statistical analysis for consumer data included descriptive statistics, One-way ANOVA and Tukey's HSD test. Level of significance was set at $p<0.05$.

Statistical analyses were performed in MS Excel 2016 (Microsoft Corporation, 2020) and EyeQuestion Data Collection v. 4.11.40 (EyeQuestion Software - Logic8 B.V. - Nieuwe Aamsestraat, The Netherlands). 
Table 4. The nutritional and chemical analysis of the Podravka and Slavonka pepper seed flour.

\begin{tabular}{cccc}
\hline & & \multicolumn{2}{c}{ FLOUR } \\
\hline Parameters & Unit & Podravka & Slavonka \\
\hline ENERGY & $\mathrm{kcal} / \mathrm{kJ} / 100 \mathrm{~g}$ & $407 / 1674$ & $404 / 1663$ \\
PROTEINS (Dumas method) & $\mathrm{g} / 100 \mathrm{~g}$ & $16.70 \pm 0.37 \mathrm{a}$ & $16.50 \pm 0.17 \mathrm{a}$ \\
FATS & $\mathrm{g} / 100 \mathrm{~g}$ & $27.20 \pm 0.54 \mathrm{a}$ & $26.70 \pm 0.79 \mathrm{a}$ \\
SATURATED FATTY ACIDS & $\mathrm{g} / 100 \mathrm{~g}$ & $3.18 \pm 0.06 \mathrm{~b}$ & $3.89 \pm 0.08 \mathrm{a}$ \\
CARBOHYDRATES & $\mathrm{g} / 100 \mathrm{~g}$ & $3.20 \pm 0.008 \mathrm{a}$ & $3.40 \pm 0.22 \mathrm{a}$ \\
SUGARS & $\mathrm{g} / 100 \mathrm{~g}$ & $3.16 \pm 0.05 \mathrm{a}$ & $3.02 \pm 0.05 \mathrm{~b}$ \\
FIBRE & $\mathrm{g} / 100 \mathrm{~g}$ & $41.20 \pm 0.88 \mathrm{a}$ & $42.10 \pm 1.61 \mathrm{a}$ \\
SODIUM & $\mathrm{g} / 100 \mathrm{~g}$ & $2.02 \pm 0.01 \mathrm{a}$ & $2.07 \pm 0.07 \mathrm{a}$ \\
SALT (Nax2,5) & $\mathrm{g} / 100 \mathrm{~g}$ & $5.05 \pm 0.03 \mathrm{a}$ & $5.18 \pm 0.16 \mathrm{a}$ \\
MOISTURE & $\mathrm{g} / 100 \mathrm{~g}$ & $8.80 \pm 0.22 \mathrm{a}$ & $8.50 \pm 0.17 \mathrm{a}$ \\
ASH & $\mathrm{g} / 100 \mathrm{~g}$ & $2.91 \pm 0.12 \mathrm{a}$ & $2.77 \pm 0.09 \mathrm{a}$ \\
VITAMIN C & $\mathrm{mg} / 100 \mathrm{~g}$ & $<\mathrm{L}$ & $<\mathrm{LQ}$ \\
POLYPHENOLS & $\mathrm{mg} / 100 \mathrm{~g}$ & $158.20 \pm 3.6 \mathrm{a}$ & $149.90 \pm 2.69 \mathrm{a}$ \\
TOTAL CAPSAICINS & $\mathrm{g} / 100 \mathrm{~g}$ & $<\mathrm{LQ}$ & $<\mathrm{LQ}$ \\
DRY MATTER & $\mathrm{g} / 100 \mathrm{~g}$ & $91.20 \pm 1.0 \mathrm{a}$ & $91.50 \pm 1.04 \mathrm{a}$ \\
ANTIOXIDANT POWER & $\mathrm{AU}$ & $107.00 \pm 4.55 \mathrm{a}$ & $70.00 \pm 3.74 \mathrm{~b}$ \\
REACTION TIME & $\mathrm{min}$ & $1.01 \pm 0.06 \mathrm{a}$ & $1.10 \pm 0.11 \mathrm{a}$ \\
WEIGHT & $\mathrm{mg}$ & $3.056 \pm 0.09 \mathrm{a}$ & $4.271 \pm 0.09 \mathrm{a}$
\end{tabular}

Values are mean \pm SD of three replicates; different letters within the same row indicate significant differences $(p<0.05)$.

Table 5. The determination of fatty acid content in pepper seed oils, Slavonka and Podravka varieties, obtained by $\mathrm{SC}-\mathrm{CO}_{2}$ extraction and cold pressing.

\begin{tabular}{ccccc}
\hline Fatty Acid (\%) & $\begin{array}{c}\text { SC-CO } \\
\text { Extraction }\end{array}$ & Cold Pressing & $\begin{array}{c}\text { SC-CO } \\
\text { Extraction }\end{array}$ & Cold Pressing \\
\cline { 2 - 5 } & \multicolumn{2}{c}{ Slavonka Variety } & \multicolumn{2}{c}{ Podravka Variety } \\
\hline Palmitic acid (C16:0) & $10.96 \pm 0.45 \mathrm{a}$ & $10.89 \pm 0.415 \mathrm{a}$ & $11.89 \pm 0.205 \mathrm{a}$ & $10.84 \pm 0.24 \mathrm{a}$ \\
Stearic acid (C18:0) & $3.01 \pm 0.025 \mathrm{a}$ & $2.97 \pm 0.13 \mathrm{a}$ & $3.25 \pm 0.16 \mathrm{a}$ & $3.37 \pm 0.095 \mathrm{a}$ \\
Oleic acid (C18:1) & $8.35 \pm 0.095 \mathrm{~d}$ & $8.43 \pm 0.17 \mathrm{c}$ & $8.84 \pm 0.18 \mathrm{~b}$ & $10.41 \pm 0.44 \mathrm{a}$ \\
Linoleic acid (C18:2) & $74.01 \pm 0.475 \mathrm{a}$ & $77.69 \pm 0.135 \mathrm{a}$ & $76.01 \pm 0.21 \mathrm{a}$ & $75.37 \pm 0.285 \mathrm{a}$ \\
\hline
\end{tabular}

Values are mean \pm SD of three replicates; different letters within the same row indicate significant differences $(p<0.05)$.

Table 6. Determination of tocopherols of the Podravka and Slavonka pepper seed oil obtained by SC-CO extraction and cold pressing.

\begin{tabular}{|c|c|c|c|c|c|}
\hline \multirow[b]{2}{*}{ Parameters } & \multirow[b]{2}{*}{ Unit } & \multicolumn{4}{|c|}{ OILS } \\
\hline & & $\begin{array}{c}\text { Cold Pressed Oil of } \\
\text { Podravka Pepper Seeds }\end{array}$ & $\begin{array}{c}\text { Cold Pressed Oil of } \\
\text { Slavonka Pepper Seeds }\end{array}$ & $\begin{array}{c}\mathrm{SC}-\mathrm{CO}_{2} \text { Oil of } \\
\text { Podravka } \\
\text { Pepper Seeds }\end{array}$ & $\begin{array}{c}\mathrm{SC}-\mathrm{CO}_{2} \text { Oil of } \\
\text { Slavonka } \\
\text { Pepper Seeds }\end{array}$ \\
\hline \multirow{2}{*}{$\begin{array}{c}\alpha \text {-tocopherol } \\
\alpha \text {-tocopherol } \\
\text { acetate }\end{array}$} & $\mathrm{mg} / 100 \mathrm{~g}$ & $<\mathrm{LQ}^{1}$ & $<\mathrm{LQ}$ & $<\mathrm{LQ}$ & $<\mathrm{LQ}$ \\
\hline & $\mathrm{mg} / 100 \mathrm{~g}$ & $<\mathrm{LQ}$ & $<\mathrm{LQ}$ & $<\mathrm{LQ}$ & $<\mathrm{LQ}$ \\
\hline$\beta$-tocopherol & $\mathrm{mg} / 100 \mathrm{~g}$ & $<\mathrm{LQ}$ & $<\mathrm{LQ}$ & $<\mathrm{LQ}$ & $<\mathrm{LQ}$ \\
\hline$\delta$-tocopherol & $\mathrm{mg} / 100 \mathrm{~g}$ & $<\mathrm{LQ}$ & $<\mathrm{LQ}$ & $<\mathrm{LQ}$ & $<\mathrm{LQ}$ \\
\hline$\gamma$-tocopherol & $\mathrm{mg} / 100 \mathrm{~g}$ & $80.1 \pm 1.47 \mathrm{a}$ & $65.3 \pm 2.06 b$ & $44.7 \pm 0.64 c$ & $16.0 \pm 0.78 \mathrm{~d}$ \\
\hline$\alpha$-tocotrienol & $\mathrm{mg} / 100 \mathrm{~g}$ & $<\mathrm{LQ}$ & $<\mathrm{LQ}$ & $<\mathrm{LQ}$ & $<\mathrm{LQ}$ \\
\hline $\begin{array}{c}\text { Vitamin E } \\
\text { (tocoph. Equi.) }\end{array}$ & $\mathrm{mg} / 100 \mathrm{~g}$ & $8.01 \pm 0.15 \mathrm{a}$ & $6.53 \pm 0.21 b$ & $4.47 \pm 0.06 c$ & $1.60 \pm 0.08 \mathrm{~d}$ \\
\hline $\operatorname{Vitamin} \mathrm{E}\left(\mathrm{UI}^{2}\right)$ & $\mathrm{UI} / 100 \mathrm{~g}$ & $11.90 \pm 0.22 \mathrm{a}$ & $9.73 \pm 0.31 b$ & $6.66 \pm 0.10 c$ & $2.38 \pm 0.12 \mathrm{~d}$ \\
\hline
\end{tabular}

Values are mean \pm SD of three replicates; different letters within the same row indicate significant differences $(p<0.05) .{ }^{1}$ limit of quantification (LQ) ${ }^{2}$ international unit (UI). 


\section{Results and Discussion}

\subsection{Pepper Seed Flour-Nutritional and Chemical Analysis}

Standard parameters such as moisture, fat, protein, and fibre content were determined in the pepper seeds, Podravka and Slavonka varieties (Table 4). The results showed that there were no big differences in the contents between these two varieties. The Podravka variety had higher initial moisture $(8.80 \mathrm{~g} / 100 \mathrm{~g})$ and oil content $(27.20 \mathrm{~g} / 100 \mathrm{~g})$ compared to the Slavonka variety, with lower initial moisture $(8.50 \mathrm{~g} / 100 \mathrm{~g})$ and oil content $(26.70 \mathrm{~g} / 100 \mathrm{~g})$. Consequently, dry matter of Podravka flour was $91.20 \mathrm{~g} / 100 \mathrm{~g}$, while for Slavonka flour it was $91.50 \mathrm{~g} / 100 \mathrm{~g}$. The protein content was determined by the Dumas method. The results showed slight differences in protein content among the pepper seeds of both varieties. The protein content was lower $(16.50 \mathrm{~g} / 100 \mathrm{~g})$ in the Slavonka variety compared to the content found in the Podravka variety $(16.70 \mathrm{~g} / 100 \mathrm{~g})$. Despite the differences, seeds of both varieties can be considered as a good source of protein. El-Adaway and Taha [7] found that Capsicum annuum seeds were a good source of protein (24.43\%) and oil (25.91\%), while Azabou et al. [6] found that Capsicum annuum seeds had lower values of protein (18.30\%) and oil (11.04\%). Hot pepper seeds were also shown to be a good source of protein due to the content of $21.29 \pm 0.28 \mathrm{~g} / 100 \mathrm{~g}$ found by Zou et al. [42]. These variations between protein and oil content occurred due to the differences in plant variety, climate, harvesting time, and ripening stage [43]. Some reports have shown variations in the oil content of pepper seeds in the Capsicum genus, as well as seed oil content between Capsicum annuum varieties. According to Jarret et al. [3], the means of the seed oil content among five cultivated species of Capsicum genus varied from $18.26 \%$ to $28.08 \%$ and between Capsicum annuum varieties from $21.06 \%$ to $28.08 \%$. Matthaus et al. [12] investigated 10 samples of Capsicum annuum from different locations (Turkey, Italy) and found that the oil content varied in a wide range from $8.5 \mathrm{~g} / 100 \mathrm{~g}$ to $32.6 \mathrm{~g} / 100 \mathrm{~g}$. Seed oil made of samples from Italy showed a higher oil content than those from Turkey. There were big differences in seed oil content between different varieties in Capsicum annuum species, which is not in accordance with the findings in this study. A previous study by Jarret et al. [3] showed that environment does not have a significant influence on seed oil content obtained from the same pepper variety of Capsicum annuum. They analysed the seed oil content of seven accessions from different growing seasons and locations, and found the average difference between samples of the same pepper variety to be only $2.4 \%$.

Regarding the results of the nutritional potential of the pepper seed flour, it was shown that they possess a high energy value of $407 \mathrm{kcal} / 100 \mathrm{~g}$ for the Podravka variety and $404 \mathrm{kcal} / 100 \mathrm{~g}$ for the Slavonka variety (Table 4$)$. The fat content of the Podravka seed flour was higher $(27.20 \mathrm{~g} / 100 \mathrm{~g})$ with lower values of saturated fatty acids ( $3.18 \mathrm{~g} / 100 \mathrm{~g}$ ) than the fats present in the flour of Slavonka seeds (26.70 g/100 g), but with higher values of saturated fatty acids $(3.89 \mathrm{~g} / 100 \mathrm{~g})$. Paired T-test showed significant difference in saturated fatty acid content between varieties $(p<0.05)$. There are no significant differences in seed oil content between the Podravka and Slavonka varieties, which is not in agreement with the previous study [3,12].

Regarding carbohydrate content, the flour of Slavonka seeds contained $3.40 \mathrm{~g} / 100 \mathrm{~g}$ with $3.02 \mathrm{~g} / 100 \mathrm{~g}$ of sugars, while the flour of Podravka seeds had lower carbohydrate content $3.20 \mathrm{~g} / 100 \mathrm{~g}$ with $3.16 \mathrm{~g} / 100 \mathrm{~g}$ of sugars. Embaby and Mokhtar [10] found that the carbohydrate content in sweet pepper seeds is significantly higher than that observed in this study, with the amount of $56.28 \pm 0.49 \%$ of dry weight. It can be explained by the difference in calculation due to the dietary fibre value included in the carbohydrate content.

The high amounts of fibres in the amount of $41.20 \mathrm{~g} / 100 \mathrm{~g}$ for the flour of Podravka seeds and $42.10 \mathrm{~g} / 100 \mathrm{~g}$ for the flour of Slavonka seeds indicate that the pepper seeds could be beneficial for human health due to the ability of fibres to prevent colon cancer, obesity, cardiovascular problems, and diabetes [44]. Compared with the amount of dietary fibres found in hot pepper seeds (38.76 g/100 g) by Zou et al. [42], seeds used in this study showed higher amounts of dietary fibres and they were also the main components found in Podravka and Slavonka seeds. The daily requirement of dietary 
fibre is $21-25 \mathrm{~g}$ for women and 30-38 $\mathrm{g}$ for men, depending on their age [45]. An investigation by Anderson et al., 2020 [46] showed that the unweighted mean intake values for total dietary fibre were $16.7 \mathrm{~g} /$ day for men and $15.6 \mathrm{~g} /$ day for women and concluded that normal fibre intake is below the recommended levels. Therefore, one of the main strategies identified by the World Health Organization is food fortification and this is an opportunity for the food industry to apply fibre in products and develop new fibre-rich products [47]. Dordevic et al. 2020 [48], stated that the addition of more than $1 \%$ of bamboo fibre in fruit jams significantly affected sensory properties and caused the product to not be accepted by consumers. This value was not enough to satisfy the requirement to be labelled as the source of fibre (at least 3\%), according to the [49]. Due to the high value of dietary fibre, pepper seed flour could be an ingredient for the fortification of different products, like jams, sauces and soups, but further evaluation of their nutritional, textural, and sensory characteristics, influenced by the fortification, is needed.

The results for salt showed that the flour of Podravka seeds contained $5.05 \mathrm{~g} / 100 \mathrm{~g}$ of salt, while the flour of Slavonka seeds had a higher value of $5.18 \mathrm{~g} / 100 \mathrm{~g}$. Ash content, when compared to the red pepper researched by Azabou et al. [6] was lower for both of the flours; Podravka flour contained $2.91 \mathrm{~g} / 100 \mathrm{~g}$, while Slavonka flour had $2.77 \mathrm{~g} / 100 \mathrm{~g}$. Hot pepper seeds also showed higher ash content $(4.94 \pm 0.14 \mathrm{~g} / 100 \mathrm{~g})$ [42], as well as sweet pepper seeds ( $4.88 \pm 0.15 \mathrm{~g} / 100 \mathrm{~g})$ [10] compared to the seeds used in this study.

In this study, vitamin C was not detected in Podravka seed flour or in Slavonka seed flour. However, studies have shown that ascorbic acid is present in Jalapeno peppers and its by-products, including the seeds and placenta. Sandoval-Castro et al. [50] revealed the content of ascorbic acid ranging from $0.0394 \pm 0.014 \mathrm{~g} / \mathrm{kg}$ to $0.0496 \pm 0.0008 \mathrm{~g} / \mathrm{kg}$. Silva et al. [51] investigated two different species of pepper seeds, Reus long pairal and sweet Italian, and they observed that the sweet Italian pepper seeds contained a higher amount of ascorbic acid $(0.2304 \pm 0.0011 \mathrm{~g} / \mathrm{kg})$. Total capsaicins were not detected, which indicates that the used pepper seeds were sweet, while Jalapeno peppers and their by-products were spicy, which has been proven in the study by Sandoval-Castro et al. [50], where the amount of total capsaicins ranged from $0.142 \pm 0.123 \mathrm{~g} / \mathrm{kg}$ to $0.292 \pm 0.304 \mathrm{~g} / \mathrm{kg}$. The capsaicionid content can differ between the cultivars, but the maturity stage plays an important role as well. Capsaicins are developed during maturation but also can be lost due to peroxidase activity [52].

It is well known that polyphenols contribute to the quality and the nutritional value of food, so their content, as well as their antioxidant power, were determined in this study. Polyphenols have the ability to reduce free radicals and prevent the damage they cause by providing hydrogen, quenching singlet oxygen and acting as metal chelators due to the hydroxyl groups. This study provides the confirmation of health benefits of pepper seeds due to the presence of phenolic compounds. The literature covers research on different species of pepper seeds, such as red pepper seeds, where the polyphenol content was $21.50 \mathrm{mg} \mathrm{GAE} \mathrm{g}^{-1}$ of seed extract according to Azabou et al. [6], while Sim and Sil [53] recorded that the polyphenol content was $29.10 \pm 0.18 \mathrm{mg} \mathrm{GAE} \mathrm{g}^{-1}$ of pepper seeds. Hot peppers showed different polyphenol content when compared to red peppers. According to Gurnani et al. [54], red chilli pepper seeds contained from $7.95 \mathrm{mg} \mathrm{GAE} \mathrm{g}^{-1}$ to $26.15 \mathrm{mg} \mathrm{GAE} \mathrm{g}^{-1}$ of phenolic compounds, while Jalapeno peppers had slightly lower values of polyphenols $\left(10.01 \pm 0.61 \mathrm{mg} \mathrm{GAE} \mathrm{g}^{-1}\right.$ to $13.09 \pm 0.98 \mathrm{mg}$ $\mathrm{GAE} \mathrm{g}^{-1}$ ) [50]. In this study, Podravka pepper seeds contained $158.20 \mathrm{mg} / 100 \mathrm{~g}$ of polyphenols, while Slavonka pepper seeds contained lower quantities ( $149.90 \mathrm{mg} / 100 \mathrm{~g}$ ) (Table 4). This can be explained by the fact that polyphenol content depends on the pepper cultivar [55]. The results obtained by Marin et al. [56] showed that sweet peppers had a very rich profile of polyphenols and they have observed that the maturity stage from green to red decreased the total phenolic content in peppers.

The determination of antioxidant power (AP) is performed by ESR spectroscopy and it is based on the 1,1-diphenyl-2-picryl-hydrazil (DPPH) method, with the major difference that both the antioxidant capacity and the antioxidant activity are used to qualify an antioxidant [34].

The reaction time $t_{r}$ is a measure of the reactivity of the specific antioxidant and the characteristic weight $w_{c}$ reflects the capacity of the antioxidant. Both parameters are used to calculate AP [34]. 
The results for antioxidant power determined with the DPPH radical assay showed a correlation with the concentration of phenolic compounds. Apart from phenolic compounds, vitamin $\mathrm{E}$ and unsaturated fatty acids can also influence antioxidant capacity [14]. Antioxidant power for Podravka pepper seed flour was significantly higher (107 AU), compared to the Slavonka pepper seed flour (70 AU), which is in accordance with the polyphenol content found in these two flours. This is in correlation with lower reaction time $\left(t_{r}\right)$ of Podravka seed flour (1.01 $\left.\mathrm{min}\right)$ compared to the Slavonka seed flour $(1.10 \mathrm{~min})$. The shorter the reaction time, the lower the oxidation state of polyphenols and the higher their antioxidative power.

A similar observation was presented in the study by Sim and Sil [53], where they have suggested that phenolic compounds were responsible for the antioxidant activities of red pepper pericarp and red pepper seeds. Silva et al. [51] observed that antioxidant activity was concentration-dependent for both of the analysed seeds, "sweet Italian" and "Reus long parial". According to Sousa et al. [57], the antioxidant potential of pepper seeds is the consequence of the protection of lipids stored in seeds, as well as ensuring their viability in the presence of high oxygen concentrations during the germination process. Chouaibi et al. [14] revealed that the applied extraction method can have a significant influence on the oxidative stability of the oil. The oils produced by $\mathrm{SC}^{-} \mathrm{CO}_{2}$ extraction and cold pressing had better stability than the oil extracted by Soxhlet, considering the content of phenolic compounds. Statistical analysis of instrumental data obtained by the Paired T-test showed significant difference in saturated fatty acid content, sugars, and antioxidant power $(p<0.05)$. The Podravka variety $(\mathrm{P} 1)$ has higher content of fatty acids, sugars, and higher antioxidant power than the Slavonka variety (P2). Differences in other measured parameters are not significant.

\subsection{Pepper Seed Oil—Chemical Analysis}

The determined fatty acid profile for the oils of Podravka and Slavonka seeds produced by SC-CO extraction, as well by cold pressing $(\mathrm{CP})$, revealed the same trend among the detected fatty acids. Of the saturated fatty acids, palmitic and steric acid were determined, while oleic and linoleic acid were the main unsaturated fatty acids. Palmitic acid (C16:0) was dominant among the saturated fatty acids (SFA), with the highest amount present in the Podravka oil produced by $\mathrm{SC}-\mathrm{CO}_{2}$ extraction $(11.89 \%)$, followed by stearic acid (C18:0) (3.25\%). It was found that linoleic acid (C18:2) was dominant in the oils produced from both seed varieties, using both of the methods. However, the cold pressed oil produced from Slavonka seeds had the highest amount of C18:2 (77.69\%), while its content in the oil produced by SC- $\mathrm{CO}_{2}$ extraction was the lowest compared to the other obtained oils $(74.01 \%)$ (Table 5$)$. Significant amounts of oleic acid (C18:1) were found in the cold pressed oil of Podravka seeds (10.41\%), while in other oils it was present in lower amounts; $8.35 \%$ for the oil of Slavonka seeds produced by SC-CO extraction, $8.43 \%$ for the cold pressed oil of Slavonka seeds, and $8.84 \%$ for the oil of Podravka seeds produced by SC- $\mathrm{CO}_{2}$ extraction. These findings were in accordance with the study of Azabou et al. [6], where they have found the dominance of $\mathrm{C} 18: 2(70.93 \pm 0.84)$ among the polyunsaturated fatty acids (PUFA); the dominant monounsaturated fatty acid (MUFA) was C18:1 (12.18 $\pm 0.22 \%)$, while C16:0 and C18:0 were the dominant SFAs (11.90 \pm 0.33 and $3.54 \pm 0.20)$. Konscek et al. [13] reported that variety and growing season have no influence on the fatty acid composition in spice pepper seed oil. The results showed small variations in the amount of determined fatty acid C18:2 (70.79-74.31\%), C18:1 (7.9-9.11\%), C18:0 (3.10-3.75\%), and C16:0 (11.08-12.2\%). A similar conclusion was found according to Matthaus et al. [12]; the variation in linoleic acid (C18:2) between varieties of Capsicum annuum was small $(69.5 \mathrm{~g} / 100 \mathrm{~g}-74.7 \mathrm{~g} / 100 \mathrm{~g})$, as well as for the other determined fatty acids (C16:0/10.7-14.2 g/100g, C18:0/2.5-4.1 g/100g and C18:1/8.9-12.5 g/100g). Reddy and Sarojini [9] found that chili (Capsicum annuит) seed oil contained 16.4.g/100 g of palmitic acid, $2.2 \mathrm{~g} / 100 \mathrm{~g}$ of stearic acid, 10.9.g/100 $\mathrm{g}$ of oleic acid, and $70.6 \mathrm{~g} / 100 \mathrm{~g}$ of linoleic acid.

Embaby and Mokhtar [10] suggested that the sweet pepper seed oil can be used as an edible cooking or salad oil due to the presence of high amounts of C18:2 (71.55\%). In their study, they have obtained similar values of fatty acids to those determined in this study (C16:0/12.32\%; C18:0/3.15\%; 
$\mathrm{C} 18: 1 / 12.98 \% ; \mathrm{C} 18: 2 / 71.55 \%)$. These findings are in accordance with the fact that the fatty acid composition of the species within a genus is generally similar to Jarret et al. [3].

Linoleic acid is essential in the diet, as it is incorporated into cell membranes and it is involved in the synthesis of compounds that are responsible for regulating blood pressure, as well as for inflammatory response. In addition, PUFAs are considered beneficial for health due to their ability to reduce total cholesterol and body fat [6].

Konscek et al. [13] have showed that $10 \mathrm{~g}$ of pepper seed oil as salad oil can cover $70-74 \%$ of the suggested beneficial minimum daily intake and, according to the Commission (EU) No 1924/2006 [49] and 432/2012 [58], the following statements can be used for oils: "Linoleic acid (LA) contributes to the maintenance of normal blood cholesterol levels. The beneficial effect is obtained with a daily intake of $10 \mathrm{~g}$ of LA" and "Replacing saturated fats with unsaturated fats in the diet contributes to the maintenance of normal blood cholesterol levels."

$\mathrm{Li}$ et al. [59] obtained red pepper seed oil by $\mathrm{SC}-\mathrm{CO}_{2}$ extraction with and without ethanol as a co-solvent. The results showed that the oil obtained by SC- $\mathrm{CO}_{2}$ extraction without ethanol contained a lower amount of C18:2 (46.49\%) compared to the one obtained with ethanol as a co-solvent $(48.20 \%)$, but it was the dominant fatty acid in both of the oils. Chouaibi et al. [14] obtained similar results for $\mathrm{C} 18: 2$ content to those in this study. The red pepper seed cold pressed oil had lower content of C18:2 (73.65\%) compared to the Podravka and Slavonka variety seed oils used in this study (C18:2 $75.37-77.69 \%)$, but the oil produced by SC- $\mathrm{CO}_{2}$ extraction had very similar content of $\mathrm{C} 18: 2(76.26 \%)$ to the Podravka seed oil used in this study C18:2 (76.01\%). Comparison with other oils such as soybean, sunflower, and peanut oils revealed that pepper seed oil had higher amounts of palmitic and linoleic acid [60-62] and it is classified among linoleic acid-rich edible oils.

Fatty acid compositions for both varieties and both methods are in accordance with previous results for Capsicum annuum L. species as well as linoleic acid (C18:2) content. The results showed that the variety of seeds or extraction methods had no effect on fatty acid content. Two-way ANOVA with repeated measurements indicated that there are significant differences in the content of oleic fatty acid between both varieties and extraction methods $(p<0.05)$. There was no significant influence of the variety or the extraction method on other measured fatty acids. The results showed that the variety of seeds, as well as the extraction methods, had no effect on the most dominant linoleic acid content (C18:2) of pepper seed oil.

Hence, among the analysed tocopherols, only $\gamma$-tocopherol was detected; $\alpha$-tocopherol, $\alpha$-tocopherol acetate, $\beta$-tocopherol, $\delta$-tocopherol, and $\alpha$-tocotrienol were not detected in this study (Table 6). The results showed that $\gamma$-tocopherol is the most dominant vitamin E-active compound in pepper seed oil. The highest amount of $\gamma$-tocopherol was found in the oil of Podravka pepper seeds produced by cold pressing $(80.1 \mathrm{mg} / 100 \mathrm{~g})$, followed by the amount in the oil of Slavonka pepper seeds also produced by cold pressing $(65.3 \mathrm{mg} / 100 \mathrm{~g})$. Generally, the oil of Podravka pepper seeds showed a higher amount of $\gamma$-tocopherol compared to the oil of Slavonka pepper seeds. Matthaus and Özcan [12] analysed 10 different varieties of pepper seed oil and showed that $\gamma$-tocopherol was also dominant in all of the samples, but other tocopherols were also detected ( $\alpha$-tocopherol, $\delta$-tocopherol and $\beta$-tocotrienol). The amount varied from $306.6 \mathrm{mg} / \mathrm{kg}$ (Italy, red) to $602.6 \mathrm{mg} / \mathrm{kg}$ (Anamur table, bitter) which is a lower concentration compared to the cold pressed oils obtained in this study from both seed varieties. $\alpha$-tocopherol, $\delta$-tocopherol and $\beta$-tocotrienol were present in a much lower amount $(49.8 \pm 0.8 \mathrm{mg} / \mathrm{kg}, 2.8 \pm 0.5 \mathrm{mg} / \mathrm{kg}$ and $6.1 \pm 0.5 \mathrm{mg} / \mathrm{kg})$, while these were not detected in the oils obtained in this study. Moreover, they noticed that the content of vitamin E-active compounds was higher in the pepper seed oil obtained from bitter pepper seeds, when compared to those with sweet taste. In addition, Koncsek et al. [13] did not detect $\beta$-tocopherol and $\delta$-tocopherol in cold pressed spice pepper seed oil, while the amounts of $\alpha$-tocopherol $(13.51-16.41 \mathrm{mg} / 100 \mathrm{~g}$ ) were significantly lower compared to the dominant $\gamma$-tocopherol $(57.85-83.57 \mathrm{mg} / 100 \mathrm{~g})$. They found a big variation in $\gamma$-tocopherol content of pepper seed oil among different varieties and harvest seasons and concluded that $\gamma$-tocopherol content in pepper seed oil was significantly affected by raw material variety and the 
growing season factors and their interactions. The results in this study match the previous results. There is significant variation in $\gamma$-tocopherol content between cold pressed pepper seed oil of Podravka and Slavonka varieties (80.1-65.3 mg/100 g), as well as between Podravka and Slavonka pepper seed oil obtained by SC- $\mathrm{CO}_{2}(44.7-16.0 \mathrm{mg} / \mathrm{kg})$. The obtained results for $\gamma$-tocopherol content showed variations between extraction methods and varieties too. $\gamma$-tocopherol content in Podravka and Slavonka seed oil obtained by cold pressing were higher than $\gamma$-tocopherol content obtained by SC-CO $\mathrm{CO}_{2}$ for both varieties. These values do not match those found by Chouaibi et al. [14] for $\gamma$-tocopherol content in pepper seed oil obtained by SC-CO ${ }_{2}$ extraction $(130.56 \mathrm{mg} / \mathrm{kg})$ and $\gamma$-tocopherol content of cold pressed pepper seed oil $(113.24 \mathrm{mg} / \mathrm{kg})$. There are significant variations in $\gamma$-tocopherol content between two extraction methods inside one variety. When it comes to vitamin $\mathrm{E}$, there are significant differences and a noticeable influence of the variety and the extraction method on the content of vitamin $\mathrm{E}$ (tocoph. equi.).

According to the study performed by Gunstone [60], $\gamma$-tocopherol protected the cold pressed spice pepper seed oils from autooxidation and provided oxidative stability to the oils. This was confirmed in the study by Yang et al. [63], where it was shown that capsaicins and tocopherols protected pepper oil from thermal oxidation during frying.

This study showed significant differences in $\gamma$-tocopherol content between two varieties of pepper seed oil, as well as between two extraction methods.

\subsection{Pepper Seed Oil-Sensory Evaluation}

Sensory profile of the samples was described by the 11 attributes (Table 7) of taste, odour, and appearance. Sensory evaluation was performed on the pepper seed oil produced by the $\mathrm{CP}$ and SC-CO extraction methods. Overall, the results did not show significant differences between oil samples. Both obtained pepper seed oils had dark orange-red colour, pleasant odour, and the characteristic taste of pepper. When compared to the obtained oils of both the Podravka (P1) and Slavonka (P2) varieties, it was noticed that the pepper seed oil produced by cold pressing $(\mathrm{CP})$ had more characteristic flavour than the one produced by SC- $\mathrm{CO}_{2}$ extraction. The sensory properties of the pepper seed oil confirmed that this oil could be applied in the food industry as salad oil or cooking oil for the preparation of spreads, soups, stews, and meat. Koncsek et al. [13] evaluated the technological and nutritional properties of the cold pressed spice pepper seed oil and concluded that it can be used in many food industries, as cooking and salad oil, due to the high content of phytonutrients.

Table 7. Description of attributes used in the sensory analysis of pepper seed oils by the trained panel.

\begin{tabular}{cc}
\hline Attribute & Description \\
\hline Orange colour & Intensity of orange colour, from light yellow to dark red-orange. \\
Turbidity & Attribute of appearance relating to cloudiness of the oil. \\
Red pepper odour & The odour associated with red bell pepper fruits. \\
Red pepper aroma & The aroma associated with red bell pepper fruits. \\
Nutty odour & The odour associated with raw nuts. \\
Nutty flavour & The flavour associated with raw nuts. \\
Waxy & The aroma associated by candle wax. \\
Bitterness & Fundamental taste sensation elicited by caffeine, quinine. \\
Spiciness & Burning sensation coming from vegetables such as hot pepper. \\
Viscosity & Texture attribute related to resistance to flow. \\
Mouthcoating & Attribute related to the oil lingering in mouth after swallowing. \\
\hline
\end{tabular}

The sensory profile of two different oil extraction techniques on two varieties of pepper seeds (Table 8) results in a slight difference in colour; the difference is significant between cold pressed oil samples $(\mathrm{P} 1-\mathrm{CP})$ and supercritical $\mathrm{CO}_{2}$ extraction processed samples $\left(\mathrm{P} 1-\mathrm{SC}-\mathrm{CO}_{2}\right)$ without a big impact of variety $(p<0.01)$. Samples P1-CP and P2-CP have a slightly darker, more intense orange colour than 
P1-SC- $\mathrm{CO}_{2}$ and P2-SC- $\mathrm{CO}_{2}$. Turbidity shows a difference in variety; the P1 in both extraction methods is slightly clearer than the P2 samples, but not significantly.

Table 8. Quantitative descriptive profile ${ }^{\circledR}$ of four samples of pepper seed oil obtained by different extraction processes.

\begin{tabular}{|c|c|c|c|c|}
\hline & P1-CP ${ }^{1}$ & $\mathrm{P} 2-\mathrm{CP}^{2}$ & P1-SC-CO ${ }_{2}^{3}$ & P2-SC-CO ${ }_{2}^{4}$ \\
\hline Orange color ** & $67.25 \pm 3.06 \mathrm{a}$ & $60.77 \pm 3.62 \mathrm{ab}$ & $54.48 \pm 3.04 b$ & $58.56 \pm 2.91 \mathrm{ab}$ \\
\hline Turbidity & $4.45 \pm 2.27 \mathrm{a}$ & $7.51 \pm 4.25 \mathrm{a}$ & $4.05 \pm 1.84 \mathrm{a}$ & $4.92 \pm 2.34 \mathrm{a}$ \\
\hline Red pepper odor & $59.11 \pm 4.37 \mathrm{a}$ & $58.24 \pm 4.19 \mathrm{a}$ & $50.74 \pm 4.51 \mathrm{a}$ & $54.2 \pm 4.39 \mathrm{a}$ \\
\hline Nutty odor & $37.62 \pm 5.54 a$ & $34.29 \pm 5.37 a$ & $38.67 \pm 4.48 \mathrm{a}$ & $38.6 \pm 5.74 a$ \\
\hline Biterness & $10.55 \pm 2.92 \mathrm{a}$ & $7.5 \pm 1.76 \mathrm{a}$ & $15.28 \pm 5.89 a$ & $13.05 \pm 4.69 \mathrm{a}$ \\
\hline Red pepper aroma * & $55.88 \pm 3.65 a$ & $47.61 \pm 4.13 \mathrm{ab}$ & $42.81 \pm 5.44 b$ & $45.78 \pm 3.64 \mathrm{ab}$ \\
\hline Nutty flavor & $28.05 \pm 7.15 \mathrm{a}$ & $27.61 \pm 6.82 \mathrm{a}$ & $28.77 \pm 6.38 \mathrm{a}$ & $31.62 \pm 7.1 \mathrm{a}$ \\
\hline Spiciness & $30.89 \pm 4.98 \mathrm{a}$ & $28.94 \pm 5.04 \mathrm{a}$ & $29.88 \pm 6.73 a$ & $25.16 \pm 5.25 \mathrm{a}$ \\
\hline Waxy & $1.00 \pm 0.32 \mathrm{a}$ & $1.43 \pm 0.61 \mathrm{a}$ & $0.67 \pm 0.41 \mathrm{a}$ & $0.87 \pm 0.28 a$ \\
\hline Viscosity & $46.52 \pm 4.86 \mathrm{a}$ & $43.37 \pm 4.74 \mathrm{a}$ & $49.75 \pm 4.11 \mathrm{a}$ & $46.13 \pm 5.05 \mathrm{a}$ \\
\hline Mouthcoating * & $29.31 \pm 5.49 a$ & $31.84 \pm 5.72 \mathrm{ab}$ & $35.18 \pm 5.3 b$ & $34.75 \pm 5.91 \mathrm{ab}$ \\
\hline
\end{tabular}

Values are mean \pm SD of two replicates; different letters within the same row indicate significant differences $(p<0.05)$; average values and st. dev. $\left({ }^{* *} p<0.01 ;{ }^{*} p<0.05\right) .{ }^{1} \mathrm{P} 1-\mathrm{CP}-$ pepper seed oil of the Podravka variety produced by cold pressing. ${ }^{2} \mathrm{P} 2-\mathrm{CP}$ - pepper seed oil of the Slavonka variety produced by cold pressing. ${ }^{3} \mathrm{P} 1-\mathrm{SC}-\mathrm{CO}_{2}-$ pepper seed oil of the Podravka variety produced by supercritical $\mathrm{CO}_{2}$ extraction. ${ }^{4} \mathrm{P} 2-\mathrm{SC}-\mathrm{CO}_{2}-$ pepper seed oil of the Slavonka variety produced by supercritical $\mathrm{CO}_{2}$ extraction.

Odour is characteristic for red pepper, more intense in P1-CP and P2-CP than P1-SC-CO $\mathrm{C}_{2}$ and $\mathrm{P} 2-\mathrm{SC}-\mathrm{CO}_{2}$. Nutty odour is also mildly present; differences between varieties and extraction methods are not significant. Bitterness is very slightly present, without differences between varieties and extraction methods. Red pepper aroma is more expressed in the P1 variety, significantly between extraction methods for the P1 variety $(p<0.05)$. Nutty flavour is almost equally present in both varieties and extraction methods. Spiciness is more present in the P1-CP sample, but differences are not significant. There is only a slightly present waxy taste. Viscosity is typical of oils. Mouthcoating is also present to some extent, but mildly; however, there is a difference between extraction methods for the P1 variety $(p<0.05)$. A common characteristic of different seed oils is mild nutty flavour and spiciness, as shown in Aydeniz et al. [38]; in this study, those characteristics are more strongly expressed for CP oil samples. Despite the differences in the type of pepper seed oil samples, the negative attributes like bitterness of the $\mathrm{SC}-\mathrm{CO}_{2}$ oil samples were similar in intensity and the waxy taste of all oil samples was less expressed, in comparison with Yllmaz et al. [64]. Multifactor PCA analysis (Figure 3) shows that PC1 participates with $62.23 \%$, and PC2 $24.35 \%$ in the variability of samples. The sample P1-CP is characterized by a red pepper odour and aroma, and intense colour. P2-CP is characterized by turbidity and waxiness. P1-SC- $\mathrm{CO}_{2}$ is characterized by a nutty odour, viscosity, and bitterness. P2-SC-CO is characterized by a nutty flavour and mouthcoating.

The obtained results from this study also show that oils produced by cold pressing have better acceptability (Table 9) than samples produced by SC-CO $\mathrm{CO}_{2}$. The variety of pepper seed oil Podravka (P1) has significantly better acceptability than the variety of pepper seed oil Slavonka P2 obtained by both techniques $(p<0.05)$. In comparison with Y1lmaz et al. [64], hedonic test results of P1-CP showed high acceptance (8.1), which indicates a pepper oil with high potential for commercial use.

Table 9. Acceptability of pepper seed oil obtained by different extraction techniques ( $\mathrm{CP}$ and $\left.\mathrm{SC}-\mathrm{CO}_{2}\right)$ on two varieties of red pepper (P1 and P2).

\begin{tabular}{ccccc}
\hline & P1-CP & P2-CP & P1-SC-CO & P2-SC-CO \\
\hline Acceptability * & $8.1 \pm 1.71 \mathrm{a}$ & $7.4 \pm 1.92 \mathrm{~b}$ & $6.8 \pm 1.69 \mathrm{bc}$ & $6.5 \pm 2.45 \mathrm{c}$ \\
\hline
\end{tabular}

Values are mean \pm SD of two replicates; Different letters within the same row indicate significant differences $(p<0.05)$; ${ }^{*} p<0.05$. 


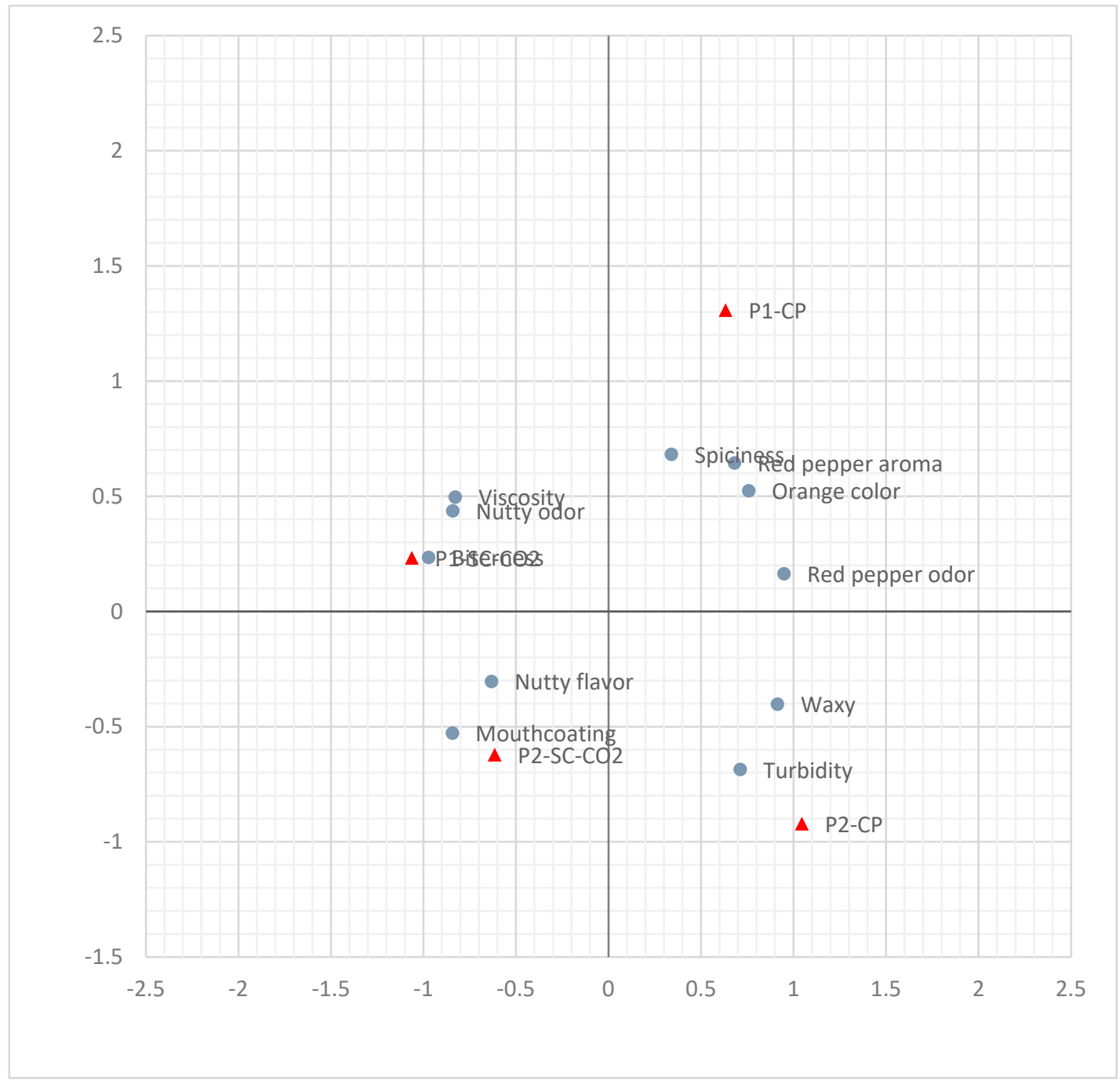

Figure 3. PCA analysis of four samples of pepper seed oil obtained by different extraction processes.

According to the sensory analysis, it can be concluded that the Podravka variety (P1) of pepper seed oil obtained by cold pressing has the most intense sensory profile, due to the darker orange colour, more intense red pepper odour and aroma, and pleasant spiciness, and it is the most acceptable according to the consumer acceptability test.

\section{Conclusions}

Pepper seed oil extraction by the cold pressing method showed to be a better technique for the extraction of natural antioxidants, which were present in the seeds; it was also better in the sensory analysis.

According to the results of the sensory evaluation and consumer testing, the pepper seed oil can be used as a valuable edible oil. Further investigations based on pepper seed oil culinary evaluations, as well as on added value product development, should be made in the future.

Due to the nutritional value of pepper seed flour, further investigations on product applications and development should be made as well. Pepper seed flour could be considered an added value ingredient for the development of new products.

We assume that the results from this study would contribute to the growing demand for recycling food by-products into new added-value products, and help food producers to achieve higher efficiency 
of production through the development of innovative and/or new ingredient(s), food product(s), and/or culinary applications.

Author Contributions: Conceptualization, T.C., J.R., S.J.; methodology, T.C., S.J.; J.R., T.M.; formal analysis, D.G., H.T.-O.; investigation, T.C., D.Š., T.M., S.J.; resources, T.C., J.R.; data curation, T.C., D.G., H.T.-O.; writing—original draft preparation, T.C., J.R., S.J., A.-M.C.; writing—review and editing, all authors.; visualization, T.C., S.J.; supervision, J.R. All authors have read and agreed to the published version of the manuscript.

Funding: This research received no external funding

Acknowledgments: This paper is a result of joint project of the Faculty of Food Technology Osijek and Podravka Ltd., Koprivnica from Croatia. We thank Podravka Ltd. for their financial support of the project.

Conflicts of Interest: The authors declare no conflict of interest.

\section{References}

1. Galankis, C.M. Recovery of high added-value components from wastes: Convencional, emerging technologies and commercialized applications. Trends Food Sci. Technol. 2012, 26, 68-87. [CrossRef]

2. Mirabella, N.; Castellani, V.; Sala, S. Current options for the valorization of food manufacturing waste: A review. J. Clean. Prod. 2014, 65, 28-41. [CrossRef]

3. Jarret, R.L.; Levy, I.J.; Potter, T.L.; Sermak, S.C. Seed oil and fatty acid composition in Capsicum spp. J. Food Compos. Anal. 2013, 30, 102-108. [CrossRef]

4. Li, M.; Wen, X.; Peng, Y.; Wang, Y.; Wang, K.; Ni, Y. Functional properties of protein isolates from bell pepper (Capcicum annuum L. var. annuum) seeds. LWT-Food Sci. Technol. 2018, 97, 802-810. [CrossRef]

5. Food and Agriculture Organization of the United Nations. The Annual Production of Dry Chillies and Peppers Reports from United Nations. Available online: http://www.fao:faostat/en/\#data/QC (accessed on 25 October 2019).

6. Azabou, S.; Taheur, F.B.; Jridi, M.; Bouaziz, M.; Nasri, M. Discarded seeds from red pepper (Capsicum annuиm) processing industry as a sustainable source of high added-value compounds and edible oil. Environ. Sci. Pollut. Res. 2017, 24, 22196-22203. [CrossRef] [PubMed]

7. El-Adaway, T.A.; Taha, K.M. Characteristics and composition of watermelon, pumpkin, and paprika seed oils and flours. J. Agric. Food Chem. 2001, 49, 253-1259. [CrossRef]

8. da Silva, A.C.; Jorge, N. Bioactive compounds of the lipid fractions of agro-industrial waste. Food Res. Int. 2014, 66, 493-500. [CrossRef]

9. Reddy, B.S.; Sajorini, G. Chemical and nutritional evaluation of chilli (Capsicum annuum) seed oil. J. Am. Oil Chem. Soc. 1987, 64, 1419-1422. [CrossRef]

10. Embaby, H.S.; Mokhtar, S.M. Chemical composition and nutritive value of lantana and sweet pepper seeds and Nabak seed kernels. J. Food Sci. 2011, 76, 736-741. [CrossRef]

11. Standard for Named Vegetable Oils Cxs 210-1999, Adopted in Revised in 2001, 2003, 2009, 2017, Amended in 2005, 2011, 2013, 2015. Available online: http://www.fao:fao-who-codexalimentarius/sh (accessed on 25 October 2019).

12. Matthäus, B.; Özcan, M.M. Chemical evaluation of some paprika (Capsicum annuum L.) seed oils. Eur. J. Lipid Sci. Technol. 2009, 111, 1249-1254. [CrossRef]

13. Koncsek, A.; Helyes, L.; Daoog, H.G. Bioactive compounds of cold pressed spice paprika seeds oils. J. Food Process. Preserv. 2018, 42, e13403. [CrossRef]

14. Chouaibi, M.; Rezig, L.; Hamdi, S.; Ferrari, G. Chemical characteristics and compositions of red pepper seed oils extracted by different methods. Ind. Crops Prod. 2019, 128, 363-370. [CrossRef]

15. List of Varieties of the Republic of Croatia. 2020. Available online: https:/www.hapih.hr/csr/sortne-liste/ (accessed on 15 June 2020).

16. Matotan, Z.; Matotan, S. Podravka i Slavonka-Prve Hrvatske Sorte Paprike s Dus Testom. Sjemenarstvo 2010, 27, 1-2.

17. Jokić, S.; Horvat, G.; Aladić, K. Design of SFE system using a holistic approach—Problems and challenges. In Supercritical Fluid Extraction: Technology. Applications and Limitations; Lindy, J., Ed.; Nova Publishers: New York, NY, USA, 2015; pp. 95-122. 
18. Regulation (EU) no. 1169/2011. European Parliament and of the Council GU L 304, 22/11/2011. Available online: https:/eur-lex.europa.eu/legal-content/EN/TXT/PDF/?uri=CELEX:32011R1169\&qid= 1590385687158\&from=EN (accessed on 15 July 2018).

19. International Organization for Standardization, ISO 16634-1:2008. In Food Products. Determination of the Total Nitrogen Content by Combustion According to the Dumas Principle and Calculation of the Crude Protein Content. Part 1: Oil Seeds and Animal Feeding Stuffs; International Organization for Standardization: Geneva, Switzerland, 2008.

20. ISO 16634-1: 2008. Available online: https://www.iso.org/standard/46328.html (accessed on 7 September 2020).

21. ISTISAN Sostanze Grasse Totali Metodo con Idrolisi Acida 1996/34. pp. 41-43. Available online: http: //old.iss.it/binary/publ2/cont/Rapporto\%2096-34.1140450878.pdf (accessed on 7 September 2020).

22. Accredited Test Procedure: 07(S46) Rev. 10 2012-GC-FID. Available online: https://www.neotron.it/en/ accedited-parameters/ (accessed on 7 September 2020).

23. Internal Method 07 (S56) 2015 Rev. 8. Available online: https://www.neotron.it/en/accedited-parameters/ (accessed on 7 September 2020).

24. Accredited Test Procedure: 07 (S47) Rev. 9 2012-GC-FID. Available online: https://www.neotron.it/en/ accedited-parameters/ (accessed on 7 September 2020).

25. AOAC 985.29 (2003); JAOAC 68, 677 (1985); 259 (1986). Available online: https://wenku.baidu.com/view/ 73702081da38376baf1fae5b.html (accessed on 7 September 2020).

26. International Organization for Standardization, HRN EN ISO/IEC 17025:2017. In General Requirements for the Competence of Testing and Calibration Laboratories; ISO/IEC 17025:2017; EPA Method 6010D ICP-OES; International Organization for Standardization: Geneva, Switzerland, 2017.

27. International Organization for Standardization, ISO 1442:1997. In Meat and Meat Products. Determination of Moisture Content; International Organization for Standardization: Geneva, Switzerland, 1997.

28. ISTISAN Ceneri Metodo Gravimetrico 1996/34. pp. 77-78. Available online: http://old.iss.it/binary/publ2/ cont/Rapporto\%2096-34.1140450878.pdf (accessed on 7 September 2020).

29. Novakova, L.; Solich, P.; Solichova, D. HPLC methods for simultaneous determination of ascorbic and dehydroascorbic acids. Trends Anal. Chem. 2008, 27, 942-958. [CrossRef]

30. Singleton, V.L.; Rossi, J.A. Colorimetry of Total Phenolics with Phosphomolybdic-Phosphotungstic Acid Reagents. Am. J. Enol. Vitic. 1965, 16, 144-158.

31. Burns, R.E. Method for Estimation of Tannin in Grain Sorghum. J. Agron. 1971, 63, 511. [CrossRef]

32. Montedoro, G.; Fantozzi, P. Dosage des tannins dans les moûts et les vins à l'aide de la méthylcellulose et évaluation d'autres fractions phénoliques. Lebensm. Wiss. Technol. 1974, 7, 155-161.

33. International Organization for Standardization, ISO 7543-2:1993. In Chillies and Chilli Oleoresins. Determination of Total Capsaicinoid Content. Part. 2: Method Using High-Performance Liquid Chromatography; International Organization for Standardization: Geneva, Switzerland, 1993.

34. Jung, K.; Richter, J.; Kabrodt, K.; Lücke, I.M.; Schellenberg, I.; Herrling, T. The antioxidative power AP-A new quantitative dependent (2D) parameter for the determination of the antioxidant capacity and reactivity of different plants. Spectrochim. Acta A Mol. Biomol. Spectrosc. 2006, 63, 846-850. [CrossRef]

35. International Organization for Standardization, HRN EN ISO 12966-2:2011. In Animal and Vegetable Fats and Oils. Gas. Chromatography of Fatty Acid Methyl Esters. Part. 2: Preparation of Methyl Esters of Fatty Acids; EN ISO 12966-2:2017; International Organization for Standardization: Geneva, Switzerland, 2011.

36. International Organization for Standardization, HRN EN ISO 12966-4:2015. In Animal and Vegetable Fats and Oils. Analysis by Gas Chromatography of Methyl Esters of Fatty Acids; ISO 5508:1990; EN ISO 5508:1995; International Organization for Standardization: Geneva, Switzerland, 2015.

37. Commision Directive 2000/45/EC. Community Methods of Analysis for the Determination of Vitamin A, Vitamin E and Tryptophan in Feeding Stuffs. Food and Agriculture Organization of the United Nations. 2000. Available online: https://eur-lex.europa.eu/legal-content/EN/TXT/PDF/?uri=CELEX:32000L0045\&qid= 1590386746912\&from $=\mathrm{EN}$ (accessed on 3 November 2019).

38. Aydeniz, B.; Güneşer, O.; Yılmaz, E. Physico-chemical, sensory and aromatic properties of cold press produced safflower oil. J. Am. Oil Chem. Soc. 2014, 91, 99-110. [CrossRef]

39. Hye-Ryun, K.; Sanjeev, K.D.; Il-Doo, K.; In-Joo, P. Physicochemical and sensory characteristics of pepper oil sauce prepared from perilla oil. Afr. J. Food Sci. 2016, 10, 352-358. [CrossRef] 
40. Leveaux, V.D.; Resurreccion, A.V.A. Descriptive sensory profiling of freshly processed commercial peanut, cottonseed, canola and soybean oils. J. Food Qual. 1996, 19, 265-277. [CrossRef]

41. Villarino, B.J.; Dy, L.M.; Lizada, M.C.C. Descriptive sensory evaluation of virgin coconut oil and rafined, bleached and deodorized cocout oil. LWT-Food Sci. Technol. 2007, 40, 193-199. [CrossRef]

42. Zou, Y.; Ma, K.; Tian, M. Chemical composition and nutritive value of hot pepper seed (Capsicum annuum) grown in Northeast Region of China. Food Sci. Technol. 2015, 35, 659-663. [CrossRef]

43. Kadri, N.; Khettal, B.; Aid, Y.; Kherfellah, S.; Sobhi, W.; Barragan-Montero, V. Some physicochemical characteristics of pinus (Pinus halepensis Mill., Pinus pinea L., Pinus pinaster and Pinus canariensis) seeds from North Algeria, their lipid profiles and volatile contents. Food Chem. 2015, 188, 184-192. [CrossRef] [PubMed]

44. Elleuch, M.; Bedigian, D.; Roiseux, O.; Besbes, S.; Blecker, C.; Attia, H. Dietary fibre and fibre-rich by-products of food processing: Characterisation, technological functionality and commercial applications: A review. Food Chem. 2011, 124, 411-421. [CrossRef]

45. Institute of Medicine. Dietary Reference Intakes for Energy, Carbohydrate, Fiber, Fat, Fatty Acids, Cholesterol, Protein and Amino Acids; The National Academies Press: Washington, DC, USA, 2005.

46. Anderson, J.W.; Baird, P.; Davis, R.H., Jr.; Ferreri, S.; Knudtson, M.; Koraym, A.; Waters, V.; Williams, C.L. Health benefits of dietary fiber. Int. Life Sci. Inst. 2020, 67, 188-205. [CrossRef]

47. Rosell, C.M.; Santos, E.; Collar, C. Physico-chemical properties of commercial fibers from different sources: A comparative approach. Food Res. Int. 2009, 42, 176-184. [CrossRef]

48. Dordevic, D.; Janickova, S.; Capikova, J.; Tremlova, B.; Kushkevych, I. Chemical and sensory properties of fruit jams affected by bamboo fiber fortification. Biointerface Res. Appl. Chem. 2020, 10, 5247-5251. [CrossRef]

49. Regulation (EC) No 1924/2006 of the European Parliament and of the Council of 20 December 2006 on Nutritiom and Health Claims Made on Foods. Available online: https:/eur-lex.europa.eu/legal-content/EN/ TXT/PDF/?uri=CELEX:32006R1924\&qid=1590388559447\&from=EN (accessed on 3 November 2019).

50. Sandoval-Castro, C.J.; Valdez-Moales, M.; Oomah, B.D.; Gutierrez-Dorado, R.; Medina-Godoy, S.; Espinosa-Alonso, L.G. Bioactive compounds and antioxidant activity in scalded Jalapeno pepper industrial byproduct (Capsicum annuum). J. Food Sci. Technol. 2017, 54, 1999-2010. [CrossRef]

51. Silva, L.R.; Azevedo, J.; Pereira, M.J.; Valentao, P.; Andrade, P.B. Chemical assessment and antioxidant capacity of pepper (Capsicum annuum L.) seeds. Food Chem. Toxicol. 2013, 53, 240-248. [CrossRef]

52. Gnayfeed, M.H.; Daood, H.G.; Biacs, P.A.; Alcaraz, C.F. Content of bioactive compounds in pungent spice red pepper (paprika) as affected by ripening and genotype. J. Sci. Food Agric. 2001, 81, 1580-1585. [CrossRef]

53. Sim, K.H.; Sil, H.Y. Antioxidant activities of red pepper (Capsicum annuum) pericarp and seed extracts. Int. J. Food Sci. Technol. 2008, 43, 1813-1823. [CrossRef]

54. Gurnani, N.; Gupta, M.; Mehta, D.; Mehta, B.K. Chemical composition, total phenolic and flavonoid contents, and in vitro antimicrobial and antioxidant activities of crude extracts from red chilli seeds (Capsicum frutescens L.). J. Taibah Univ. Sci. 2016, 10, 462-470. [CrossRef]

55. Howard, L.R.; Talcott, S.T.; Brenes, C.H.; Villalon, B. Changes in phytochemical and antioxidant activity of selected pepper cultivars (Capsicum species) as influenced by maturity. J. Agric. Food Chem. 2000, 48, 1713-1720. [CrossRef]

56. Marin, A.; Ferreres, F.; Tomás-Barberaán, F.A.; Gil, M.I. Characterization and quantitation of antioxidant constituents of sweet pepper (Capsicum annuum L.). J. Agric. Food Chem. 2004, 52, 3861-3869. [CrossRef]

57. Sousa, C.; Lopes, G.; Pereira, D.M.; Taveira, M.; Valentăo, P.; Seabra, R.M.; Pereira, J.A.; Baptista, P.; Ferreres, F.; Andrade, P.B. Screening of antioxidant compounds during sprouting of Brassica oleracea L. var. costata DC. Comb. Chem. High. Throughput Screen. 2007, 10, 377-386. [CrossRef]

58. Commision Regulation (EU) No 432/2012 of 16 May 2012 Establishing a List of Permitted Health Claims Made on Foods, Other Than Those Referring to the Reduction of Disease Risk and to Children's Development and Health. Available online: https:/eur-lex.europa.eu/legal-content/EN/TXT/PDF/?uri=CELEX:32012R0432\& qid=1590388629593\&from $=E N$ (accessed on 3 November 2019).

59. Li, G.; Song, C.; You, J.; Sun, Z.; Xia, L.; Suo, Y. Optimisation of red pepper seed oil extraction using supercritical $\mathrm{CO}_{2}$ and analysis of the composition by reversed-phase HPLC-FLD-MS/MS. Int. J. Food Sci. Technol. 2011, 46, 44-51. [CrossRef]

60. Gunstone, F.D. Vegetable Oils in Food Technology Composition, Properties and Uses, 1st ed.; CRC Press: Boca Raton, FL, USA, 2002; pp. 116, 137, 139. 
61. Kostik, V.; Memeti, S.; Bauer, B. Fatty acid composition of edible oils and fats. J. Hyg. Eng. Des. 2013, 4, 112-116.

62. Orsavova, J.; Misurcova, L.; Ambrozova, J.V.; Vicha, R.; Mlcek, J. Fatty acids composition of vegetable oils and its contribution to dietary energy intake and dependence of cardiovascular mortality on dietary intake of fatty acids. Int. J. Mol. Sci. 2015, 16, 12871-12890. [CrossRef]

63. Yang, C.Y.; Mandal, P.K.; Han, K.H.; Fukushima, M.; Choi, K.; Kim, C.J.; Lee, C.H. Capsaicin and tocopherol in red pepper seed oil enhances the thermal oxidative stability during frying. J. Food Sci. Technol. 2013, 47, 162-165. [CrossRef]

64. Yılmaz, E.; Arsunar, E.S.; Aydeniz, B.; Güneşer, O. Cold pressed capia pepper seed (Capsicum annuum L.) oils: Composition, aroma and sensory properties. Eur. J. Lipid Sci. Technol. 2015, 117, 1016-1026. [CrossRef]

(C) 2020 by the authors. Licensee MDPI, Basel, Switzerland. This article is an open access article distributed under the terms and conditions of the Creative Commons Attribution (CC BY) license (http://creativecommons.org/licenses/by/4.0/). 